\title{
Ximelagatran was non-inferior to warfarin in preventing stroke and systemic embolism in atrial fibrillation
}

Olsson SB. Stroke prevention with the oral direct thrombin inhibitor ximelagatran compared with warfarin in patients with non-valvular atrial fibrillation (SPORTIF III): randomised controlled trial. Lancet 2003;362:1691-8.

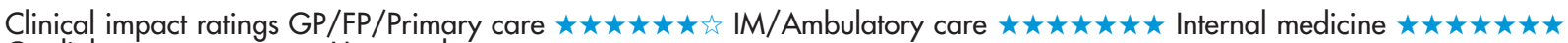

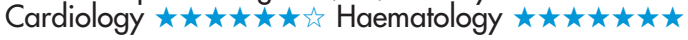

In patients with atrial fibrillation (AF) at risk for ischaemic stroke, is ximelagatran non-inferior to warfarin in preventing stroke and systemic embolism?

\section{METHODS}

\begin{tabular}{|c|c|}
\hline \multirow{2}{*}{ L } & $\begin{array}{l}\text { Design: randomised controlled trial (Stroke Prevention using an } \\
\text { ORal Thrombin Inhibitor in atrial Fibrillation [SPORTIF]). }\end{array}$ \\
\hline & Allocation: concealed. ${ }^{*}$ \\
\hline & Blinding: blinded (outcome assessors). ${ }^{*}$ \\
\hline & Follow up: mean 17.4 months. \\
\hline & $\begin{array}{l}\text { Setting: } 259 \text { hospitals, doctor's offices, and clinics in } 23 \\
\text { countries. }\end{array}$ \\
\hline & $\begin{array}{l}\text { Patients: } 3410 \text { patients } \geqslant 18 \text { years of age who had nonvalvular } \\
\text { AF and } \geqslant 1 \text { additional risk factor for stroke: treatment for } \\
\text { hypertension but blood pressure }<180 / 100 \mathrm{~mm} \mathrm{Hg} \text {; age } \geqslant 75 \\
\text { years; previous stroke, transient ischaemic attack (TIA), or } \\
\text { systemic embolism; left ventricular dysfunction; or age } \geqslant 65 \text { years } \\
\text { and coronary artery disease or diabetes mellitus. Exclusion } \\
\text { criteria included mitral stenosis or previous valvular heart } \\
\text { surgery, transient AF, stroke in the past } 30 \text { days or TIA in the past } \\
3 \text { days, risk of bleeding, and need for cardiac intervention or } \\
\text { major surgery. }\end{array}$ \\
\hline & $\begin{array}{l}\text { Intervention: ximelagatran, } 36 \mathrm{mg} \text { twice daily }(\mathrm{n}=1704) \text {, or } \\
\text { warfarin dose adjusted to maintain the international normalised } \\
\text { ratio (INR) between } 2.0 \text { and } 3.0(n=1703) \text {. }\end{array}$ \\
\hline 2 & $\begin{array}{l}\text { Outcomes: All stroke (ischaemic and hemorrhagic) and systemic } \\
\text { embolic events. Secondary outcomes included composite } \\
\text { endpoints of major and minor bleeding; ischaemic stroke, TIA, } \\
\text { and systemic embolism; and death, stroke, systemic embolism, } \\
\text { and myocardial infarction. }\end{array}$ \\
\hline$\vec{\square}$ & $\begin{array}{l}\text { Patient follow up: } 3407 \text { patients (99.9\%) were included in the } \\
\text { analysis. }\end{array}$ \\
\hline & *See glossary. \\
\hline
\end{tabular}

\section{MAIN RESULTS}

Analysis was by intention to treat. Ximelagatran was not inferior to warfarin for stroke and systemic embolism (table), or for the composite secondary endpoints. An on treatment analysis showed that ximelagatran had less combined major and minor bleeding events than warfarin, and was not inferior to warfarin for major bleeding only (table). Serum alanine aminotransferase levels increased ( $>3$ times the upper limit of normal) more with ximelagatran than warfarin $(6 \% v 1 \%, \mathrm{p}<0.001)$.

For correspondence: Professor S B Olsson, University Hospital, Lund, Sweden. bertil.olsson@kard.lu.se

Source of funding: AstraZeneca.

\section{CONCLUSION}

In patients with atrial fibrillation at risk of ischaemic stroke, ximelagatran was non-inferior to warfarin in preventing stroke and systemic embolism.

\section{Abstract and commentary also appear in ACP Journal Club.}

Ximelagatran $v$ warfarin in patients with atrial fibrillation at risk of ischaemic stroke at mean 17.4 months*

\begin{tabular}{|c|c|c|c|}
\hline \multirow[b]{2}{*}{ Outcomes } & \multicolumn{2}{|c|}{ Event rates per year } & \multirow[b]{2}{*}{ Difference $(95 \% \mathrm{Cl})$} \\
\hline & Ximelagatran & Warfarin & \\
\hline $\begin{array}{l}\text { All stroke and } \\
\text { systemic } \\
\text { embolism† }\end{array}$ & $1.6 \%$ & $2.3 \%$ & $-0.7 \%(-0.1$ to 1.4$) \S$ \\
\hline $\begin{array}{l}\text { Major or minor } \\
\text { bleeding } \ddagger\end{array}$ & $25.8 \%$ & $29.8 \%$ & $-4.0 \%(-6.9$ to -1.1$)$ \\
\hline Major bleedingf & $1.3 \%$ & $1.8 \%$ & $-0.5 \%(-1.2$ to 0.2$) \S$ \\
\hline \multicolumn{4}{|c|}{$\begin{array}{l}{ }^{*} \mathrm{Cl} \text { defined in glossary. } \\
\text { †lntention to treat analysis. } \\
\text { fOn treatment analysis. } \\
\text { §Not significant. }\end{array}$} \\
\hline
\end{tabular}

Commentary

C PORTIF III compared ximelagatran, $36 \mathrm{mg}$ twice daily, with therapeutic warfarin in patients with AF at moderate to high risk of thromboembolic outcomes. INR control in the warfarin group was similar to that in the community. ${ }^{1}$ The results, along with the recently reported SPORTIF $V_{1}{ }^{2}$ showed that ximelagatran is at least as efficacious as warfarin and at least as safe for bleeding complications. See EBM notebook (http://ebm.bmijournals.com/cgi/content/9/2/38). From a practical standpoint, ximelagatran is an easier drug to use than warfarin because it can be administered in a fixed dose regimen, without the need for laboratory monitoring of its anticoagulant effect to make dose adjustments, and does not appear to have drug and food related interactions that occur with warfarin. These advantages have the potential to greatly simplify the anticoagulant management of patients with AF. However, ximelagatran is potentially hepatotoxic (see table on web site). ${ }^{345}$ Most studies of long term ximelagatran showed almost all patients were asymptomatic and about half had complete resolution of transaminitis despite continuing the drug. With few exceptions, transaminases resolved in the remaining patients after the drug was stopped. Although patients treated with ximelagatran will require hepatic monitoring in the initial 3 months of therapy, the intensity of such monitoring will probably not match that required for long term warfarin therapy.

Carl van Walraven, MD Ottawa Health Research Institute Ottawa, Ontario, Canada

1 Wilson SJ, Wells PS, Kovacs MJ, et al. CMAJ 2003;169:293-8.

2 Verheugt FW. Lancet 2003;362:1686-7.

3 Petersen P, Grind M, Adler J. J Am Coll Cardiol 2003;41:1445-51.

4 Wallentin L, Wilcox RG, Weaver WD, et al. Lancet 2003;362:789-97.

5 Schulman S, Wahlander K, Lundstrom T, et al. N Engl J Med 2003;349:1762-4. 